\title{
Miranda
}

Revue pluridisciplinaire du monde anglophone /

Multidisciplinary peer-reviewed journal on the English-

speaking world

5 | 2011

South and Race / Staging Mobility in the United States

\section{Forgetting the South and the Southern Strategy}

\section{Michelle Brattain}

\section{OpenEdition}

\section{Journals}

Electronic version

URL: http://journals.openedition.org/miranda/2243

DOI: $10.4000 /$ miranda.2243

ISSN: 2108-6559

\section{Publisher}

Université Toulouse - Jean Jaurès

Electronic reference

Michelle Brattain, "Forgetting the South and the Southern Strategy", Miranda [Online], 5 | 2011, Online since 29 November 2011, connection on 16 February 2021. URL: http://journals.openedition.org/ miranda/2243 ; DOI: https://doi.org/10.4000/miranda.2243

This text was automatically generated on 16 February 2021.

\section{$(1) \Theta \Theta$}

Miranda is licensed under a Creative Commons Attribution-NonCommercial-NoDerivatives 4.0 International License. 


\title{
Forgetting the South and the Southern Strategy
}

\author{
Michelle Brattain
}

1 Let's begin with a true story about the modern South.

2 In 2002 the Dodge County (GA) commission voted to fly the Confederate Battle flag outside their courthouse one day a year in honor of Confederate Memorial Day (Bennet). Given the simultaneous uproar over the placement of the stars and bars on Georgia's state flag-the official state banner changed three times in the space of just twenty-seven months prior to May 2003-Dodge County's policy seemed a moderate, even temperate, compromise between those who wished to honor "Southern" history and those who argued that the stars and bars should not have any official sanction by the state. Until 2001, Georgia had flown the 1956 state flag, adopted by segregationist legislators in the heat of massive resistance, which defiantly devoted two-thirds of the flag's real estate to the Confederate stars and bars. At the time, the Democratic Governor's floor leader had declared that the flag would "show that we in Georgia intend to uphold what we stood for, will stand for and will fight for"-in other words, segregation (Martinez 224). But times had changed in the twenty-first century, and led by Democratic Governor Roy Barnes, the legislature adopted a new, somewhat awkward, compromise design giving equal space to all five flags that had historically flown over the state, including the Confederate battle flag but also two American flags. However, this aesthetically-challenged flag, like Barnes, would not be long for Georgia. ${ }^{1}$

3 As Sons of Confederate Veterans (SCV) and the Heritage Preservation Association demanded a return of the Stars and Bars, Republican gubernatorial candidate Sonny Perdue announced his support for a referendum on the flag. In 2002, this position won Perdue, formerly a state senator and a Democrat, enough white rural votes to defeat Barnes and make him the first Republican Governor of Georgia since Reconstruction. Two-thirds of Georgians, according to an Atlanta Journal-Constitution poll, wanted a flag referendum, and more than half considered the stars and bars a symbol of Southern heritage (Wilson and Silk 183). But the referendum on the 1956 flag never came to pass. After the election Perdue began distancing himself from Confederate symbols, even 
banning the flag's display at his inauguration. Angry "flaggers" protested with three small planes flying over the inauguration with thirty-three-foot banners displaying the 1956 flag and demanding: "Let us vote. You Promised" (Galloway, 2003, 1A). In 2004 the referendum took place, but the choices were limited to the Barnes flag and yet another new stars-and-bars-free design, outraging the "flaggers" and eliciting a sigh of relief from Republicans worried about tainting the party's image in an election year and probusiness Georgians worried about what kind of message that might send about the state ("Phew" Economist). Flaggers now threatened to throw their support to a Democrat in the next gubernatorial election, "just to send a message", according to a member of the Heritage Preservation Association (Galloway 2004, 1D). As "Sonny Lied" signs began popping up on highways throughout rural Georgia and flaggers vowed to seek revenge at the ballot box, Dodge County's 2002 decision must have appeared quite extraordinary-a model of a New South committed to remembering history, not reliving it.

4 The only thing was that Dodge County's Commissioners didn't remove the flag after Confederate Memorial Day. They never took it down. It has been flying continuously outside the courthouse in Eastman, Georgia for nearly a decade (Bennet). In 2011 when the President of the Dodge County NAACP asked the county to comply with the original law, the majority-white county commission, anticipating a law suit from either the NAACP or the SCV no matter what they did, passed a new law permitting year-round display of the battle flag-which is now padlocked to the pole (Bennet, Richards).

5 Perhaps the never-ending saga over the Confederate flag is low-hanging fruit in the quest to make a point about Southern exceptionalism. White racial insensitivity is undoubtedly not unique to the South (Sugrue 209-258, McGirr 185, 305). As a Southern transplant attending graduate school in New Jersey, I still remember the shock of discovering that 1 . Whites outside the South were not universally racial liberals and 2 . "Northerners" nevertheless made many assumptions about all white Southerners, including me. Seven years at Rutgers University cured me of a telltale Charlotte, NC accent but it also motivated me to do Southern history, because I was certain that "myth" and the desire to exoticize the South had prevented historians from seeing its complexity. I remember feeling compelled to challenge scholarly assumptions about a universal white Southern identification with the Confederacy and to inform fellow students in a Southern history seminar that in fact my family never sat around the supper table romanticizing the Lost Cause or rehashing Civil War battles. It was wrong, and perversely ahistorical, to assume a direct line of continuity between the $19^{\text {th }}$ and the $20^{\text {th }}$ century South. Other aspects of "Southern" distinctiveness, however, rang uncomfortably true for me, especially in recent history. There were no Klan members hidden in my family closets, but it was true that my parents were Nixon-era converts to the Republican Party, motivated in no small part by school busing and their sense that Nixon represented the "high-class" alternative to men like George Wallace and (thenDemocrat) Jesse Helms. My folks never advocated integration and they hated busing, but they were good Southern folk with the "right" raising, who had enough sense to be moderate and polite about their demands.

6 So my own response to the recent scholarly trend of declaring the "end of Southern history" and the "myth" of Southern exceptionalism has been ambivalence. On the one hand, I understand the impulse to expose the myth of American racism as an exclusively Southern phenomenon and to do justice to the genuine complexity of 
Southern history. My own dissertation research was motivated by my desire to show that white Southern workers were more than the hapless counterparts of the other "American" workers or victims of false consciousness disciplined by the threat of a phantom black industrial army waiting to steal their jobs. There was then, and probably still is, a hardy tradition of thinking of the South as the anomaly in a norm of "American" history (Lassiter and Crespino 7-11). That faith has long justified Southern history's existence as a traditional subfield that, in spite of many scholarly challenges, predictably rises from the ashes like a phoenix every time a new cohort of historians offers a dedicated graduate seminar, presents their work at regional conferences, or publishes in specialized journals. The indisputable truth that all Southern historians have to face is that the South has at times been quite different-obviously because of the extent and duration of slavery, secession and the Civil War, Reconstruction, the segregation and disfranchisement of black voters, and more recently the very visible, public civil rights movement and an equally visible opposition. The South has historically been more rural, agrarian, and poor, with distinctively low rates of unionization and an economy dominated in the first half of the twentieth century by low-wage industries. Its politics have also been historically peculiar, functioning as a de facto one-party state dominated for nearly a century by the Democratic Party and profoundly shaped by near universal black disfranchisement. And even within the Democratic Party, Southerners were frequently distinctive: consistently anti-union, anti-civil rights, pro-military, anti-communist to the extreme, and more conservative generally, voting more frequently with conservative Republicans than Democrats in Congress.

7 Even as the South was transformed in the second half of the twentieth century, presumably becoming more urban, suburban, industrial, and diverse-e.g. "American"-it still seemed to change and act as a region, especially in politics. First in 1964, the once reliably Democratic South began to withdraw its loyalty to the national party that had begun to champion black civil rights. In the 1964 Presidential election, five deep-South states threw their support to the Republican candidate, Barry Goldwater, one of a handful of Senators that had voted against the Civil Rights Act. In 1968, Southern states divided between Republican Richard Nixon and former Alabama Governor and Independent George Wallace, but roundly rejected the Democrats, seemingly forever. Almost overnight, the single-party, solid South was no more. White Southern voters, and white Southern politicians, shifted in droves to the Republican Party in national elections, making the South a new Republican and conservative stronghold. (Lesher, 311-313, 436; Rieder 243-69; Black and Black 1-39).

Wrapped up in this narrative of party realignment is the most "modern" article of faith behind Southern exceptionalism: the Republican "Southern strategy." Richard Nixon and his advisors, the story goes, stole a page from the Goldwater and Wallace playbooks and wooed white Southern voters into the Republican party with appeals to festering racial resentments. But they didn't act like Southern segregationists or openly champion white supremacy. Rather, the Republicans employed a coded language of "state's rights," "law and order," and "forced busing." (Carter 1996 xi-xiv, Rieder 243-69) As Nixon aide John Erlichman later described it in Witness to Power, Nixon took strong positions on busing, quotas, and crime, but "always couched his views in such a way that a citizen could avoid admitting to himself that he was attracted by a racist appeal." There were, for example, "plausible reasons to be against open housing that had nothing to do with the fact that most public-housing-project dwellers" were 
minorities, so that's what they offered. (Erlichman 223, Carter 1996, 30). Such disingenuous campaigning, invented by Wallace and perfected by Nixon, some scholars have argued, has kept the white South unapologetically coming back for more "colorblind" Republicanism every four years.

It's this last chapter in Southern exceptionalism that has recently come under fire. As one historian put it bluntly: "The 'Southern strategy' explanation of the political transformation of the modern South is wrong" (Lassiter 2006, 5). Moreover, as coeditors and contributing authors to the 2009 anthology The Myth of Southern Exceptionalism, Matthew Lassiter and Joseph Crespino argue that the "notion of the exceptional South has served as a myth, one that has persistently distorted our understanding of American history." Their goal is not to "absolve the South but to implicate the nation" (Lassiter and Crespino 7). Neither denies the history of racism in the South or its role in Southern-style massive resistance. Rather both argue that the tendency to associate white racism exclusively with the South-a practice perpetuated by South-centered accounts of the Civil Rights movement and the "Southern strategy" account of partisan political realignment-has obscured the presence of white racism and racially inflected politics elsewhere in the United States. As they point out, two weeks before President Eisenhower sent the National Guard to protect black students from segregationist mobs in Little Rock, Arkansas, the Governor of Pennsylvania was forced to dispatch state troopers to the Philadelphia suburb of Levittown. There, a white mob of 400 people turned out to protest a black family that had just moved in, tormenting them with loud music and car horns, vandalizing their home, and displaying a Confederate battle flag. Clashes between the Pennsylvania troopers and residents lasted for a week. Americans remember Little Rock, but not Levittown. The reason, Lassiter and Crespino suggest, is because history and popular memory have "reinforce[d] a selective historical consciousness about the civil rights era, which is typically portrayed as an epic showdown between the retrograde south and a progressive nation." (4-7). In reality, they argue, "most regional characteristics cited as evidence of difference of kind are really differences of degree." (12). Thus contributors to The Myth of Southern Exceptionalism frequently turn their gaze elsewhere-reminding us not only that whites rioted against housing integration in Pennsylvania, but that segregation (of the Chinese) existed out west, and that NY prisons could be as brutal as Mississippi's notorious Parchman Farm.

But the most vociferous challenges to Southern exceptionalism have come primarily through scholarship of the South itself. Unlike the old "top-down" arguments suggesting that Nixon orchestrated the late 1960s "backlash" against Civil Rights, these authors all describe a quiet revolution from below. Republicans did not "Southernize" the nation; rather the dramatic economic and social changes that swept through the South after the 1950s dramatically transformed the region, making it more like the rest of the nation (even if contemporaries tended not to notice). In the process, political power shifted from the rural Black Belt to the metropolitan frontiers of the sunbelt. Although the emphasis varies across this new scholarship, two factors are thought key: the urbanization and more importantly suburbanization of the South, and as a result, the mobilization of Southern whites around new "colorblind" conservative political issues such as private schools, busing, or social values (Lassiter 2006, 225-250, Kruse 259-266, Crespino 205-206, 271). In a move that has been long overdue, these new works simultaneously reveal the existence of a wide variety of opinion and conviction about race from the 1950s through the 1980s. The white South had its William Simmonses and 
Bull Connors and its Anne Bradens and Connie Currys, but there were a lot, a majority in fact, of people in between who varied in their commitment to segregation, who were willing to follow the law-even if they did not like it, and who actually adjusted themselves and their politics to the new racial order (Lassiter 251-275, Kruse 138-139). Judge Tom P. Brady, Mississippi author of the notorious Black Monday is a case in point. Though as a leader of the Citizens' Council he authored some of the most vicious racial propaganda produced during the massive resistance era, on the bench he did his duty to uphold the law, "irrespective of how erroneous it may appear, or how odious it is," because "a decision of the United States Supreme Court is still the ultimate in judicial determination and is binding on the tribunals and citizens of the respective states." (Crespino 175).

11 All the new Southern revisionists emphasize how demographic changes transformed the politics of both the South and the nation. Lassiter, for example, suggests that the key to understanding partisan political realignment after 1964 is not the exploitation of Southern politics, but suburban politics, which were a national phenomenon with profoundly racial implications (Lassiter 2006, 3-5, Lassiter 2004). In the South, as elsewhere, the suburbs were produced by entrenched racial structures, from restrictive covenants to the FHA's racially skewed method of awarding mortgage subsidies, which, by the 1960s, had helped generations of whites accumulate substantial economic and cultural capital. The suburbs also provided a haven for whites fleeing municipal integration. In Atlanta, when segregationist efforts were foiled by white city elites content to desegregate public facilities that elites didn't use anyway, blue-collar and middle-class whites fled to the suburbs, where, in Kevin Kruse's words, they "made their dreams manifest in the spatially and socially removed lands of suburbia" far from the "pollution, bad schools and crime" they associated with the integrated city (Kruse 247). Outside the perimeter in places like Cobb and Gwinnett County, secessionists were joined by new suburbanites, who had not necessarily participated in the original migration from Atlanta, but readily adopted the same political mantras of low taxes and individualism, which, in practice, were racial politics nonetheless (Kruse 243-266). Political Scientists Byron E. Shafer and Richard Johnston argue that these economically based preferences, rather than race, were the primary force transforming the South into a new Republican stronghold. However, as Lassiter and Kruse point out, this new politics was different from and more than simple racism, since middle class status insulated middle class and affluent whites from racial others nearly as effectively as whiteness. Suburbia was also one of those racial advantages that many white Americans forgot about very quickly, embracing instead what Lassiter calls a myth of "racial innocence" (Lassiter 2004, 558). But, significantly, it was a myth they shared with suburban whites all over the country. Ironically no one understood this better than Mississippi Senator John Stennis, who protested in 1970 that federal policy unfairly targeted the de jure segregation of the South while leaving the de facto segregation of Northern, Western and Midwestern suburbs intact (Crespino 175).

12 To those who are tempted to draw a straight line from Goldwater, through Wallace, to Nixon and beyond as evidence of Republicans manipulating white Southerners through carefully coded appeals to their racism, the new critics of Southern exceptionalism point to other, less-well-known forces working at the grassroots of Southern politics and culture-namely, moderation. This was true, as historian Joseph Crespino shows, even in the "most Southern place on earth": Mississippi. ${ }^{2}$ Though Crespino unflinchingly recounts the familiar and undeniable violence of Mississippi's white 
supremacists and the below-the-belt tactics of its Citizens' Council, he also documents the early emergence of a new, business-oriented, urban and suburban political elite who were committed to projecting an image of moderation while preserving the racial status quo. This Mississippi would be unrecognizable to a casual acquaintance familiar only with the Mississippi of "Eyes on the Prize." Even the Sovereignty Commission, the notorious state surveillance agency formed to monitor and discourage civil rights activity in Mississippi, had by the early 1960s added white extremist organizations to its list of charges, attempting to channel white resistance into "more subtle and effective strategies." In line with the political wisdom of Commission director Erle Johnston, for example, the Americans for the Preservation of the White Race, had, by 1965, stopped using words "nigger" or "Negro," replacing them with "'communists' or subversive individuals" (Crespino 108). As Crespino documents so well, Mississippi didn't need Republican presidential political strategists or white suburbanites to invent "conservative color blindness and racist code words" (Crespino 8) because they had them all along: "states' rights," after all, had never required anyone to use the N-word. Thus the Civil Rights Act was a "dangerous and unconstitutional expansion of federal powers" and school busing violated "freedom of choice." Mississippi Republicans likewise attempted to work defenses of racial tradition into a broader platform of conservative ideology.

13 By 1970, Lassiter argues, white Southerners preferred moderate policies and candidates who employed a language of abstract principles over open defiance and political extremists-a lesson that Nixon learned the hard way. One of the few "genuine" incarnations of the Southern strategy, Lassiter argues, was Nixon's decision in the 1970 midterm elections to lend his support to the Southern Republican candidates who represented the most extreme racial backlash to court-ordered school desegregation and busing. In theory (Kevin Phillip's theory to be precise) such a strategy would have hastened Southern partisan realignment. However, centrist Democrats triumphed over race-baiting Republicans in several key gubernatorial and Congressional elections. By 1970, Southern suburbanites, like their American counterparts, seem to have rejected massive resistance in favor of moderates who, in the very least, paid lip service to integration and "equal rights" while opposing busing and "special treatment" (Lassiter 2006, 251-275). In Charlotte, NC, for example, subject of the infamous Swann v. CharlotteMecklenberg Board of Education (1971) Supreme Court case, the white suburbanites who formed the Concerned Parents Association to oppose "two-way" school busing were not racists in the conventional sense. Unlike the old adherents to massive resistance, they did not categorically reject integration in principle. Rather they considered themselves "good citizens," who had had the foresight and affluence to purchase homes in neighborhoods with good schools whose rights as taxpayers and consumers were now being violated (Lassiter 2006, 121-147, Lassiter 2004). It was in this capacity, not as white Southern racists, Lassiter argues, that white Southern suburbanites actually identified with Nixon and the "Silent Majority."

14 Such reexaminations of Southern political, social, and cultural history have been long overdue, and they have made enormous contributions to late twentie ${ }^{\text {th }}$ century US history. The national success of Nixon's appeal to middle-class whites who disdained social engineering in the name of racial equality is an extraordinarily important historical insight that challenges myths about American racial innocence. The similarity of white responses to busing across regions, for example, and the hypocrisy of Hubert Humphrey and other non-Southern Democratic liberals who resisted the application of 
integrationist remedies in their own backyards has newly exposed the emptiness of distinctions between de jure and de facto segregation (Crespino 178-180). The triumph of "moderate" politics in the South of the 1970s over the diehard segregationists still beating the same drum likewise challenges any scholar who would draw a straight historical line of continuity between the Dixiecrats and the Southern Republican party. But is it time to forget the Southern strategy and declare the "end of Southern history"?

One remaining-and substantial-hurdle is that the "Southern strategy" still explains a lot about national politics, even if the details need modification. Perhaps the "Southern strategy" was not as successful as Kevin Phillips, author of the New Republican Majority, assumed it would be, but it is nevertheless very difficult to deny that the National Democratic Party's open embrace of federal civil rights legislation contributed to a fundamental political realignment in the United States beginning in 1964. Even Lyndon Johnson expected to lose white voters in Southern states after passage of the Civil Rights Act. On the other side of the coin, Phillips predicted that the Republicans would never again get more than " 10 to 20 per cent of the Negro vote" after determining to go "where the [potential new Republican] votes are" (Boyd 106). And both were correct. The regional and racial repositioning that occurred after 1964 can be described and circumscribed in many ways: as the dissolution of the New Deal coalition, as a shift limited to Presidential politics that proceeded in fits and starts until the 1980s, or the Republicans' successful seduction of disaffected white Southern voters. But it's undeniable that most Southern states gave up their knee-jerk support for the national Democratic Party, and this was an extraordinary development. Let's recall that we're talking about states that were so firmly Democratic at the national level that they even supported Adlai Stevenson in 1956. We can never be entirely sure what precise slogan or policy attracted each individual white Southerner who cast a vote for Goldwater, Wallace, Nixon, or later, Reagan, but there were quite a few who openly declared that it was the Democrat's support for national civil rights legislation. In any case, a great number of them obligingly trooped the polls and acted according to contemporary predictions.

16 There's also the problem of all those smoking guns that the Republicans left behind. "Coded language" was not the modern invention of historians, it was an open secret in the Nixon political camp. Although Nixon and many other Republican operatives were often guarded or defensive about the Republicans' relationship to the white South in the $1960 \mathrm{~s}$ and 1970s, their memoirs, recordings, and internal documents unapologetically rehash their efforts to court white Southern voters with appeals to race. Special Nixon commercials were created for Southern audiences, many featuring Strom Thurmond "talking about crime, busing, and the Supreme Court"-all issues that had been inseparable from race for the past 15 years, and were firmly racialized in the context of the federal government's 1968 hardline position on Southern desegregation plans (McGinnis 122). Or take Nixon's position on "law and order." In 1968, after four summers of urban populations across the United States exploding into open racial rebellion, Nixon recorded a television ad bemoaning the "decline of 'law and order' in American cities." The ad itself did not mention race, but viewing it, Nixon declared that this campaign spot "hits it right on the nose...It's all about law and order and the damn Negro-Puerto Rican groups out there" (Carter 1996, 30). Nixon's campaign advisors even edited out an image of a little boy "staring in the smoldering ruins of what had 
been his home" because it might suggest "sympathy for Negroes who riot" (McGinnis 116).

17 Some Republicans have been forthcoming about how this tradition was carried over into later decades. While many denied that Ronald Reagan's decision to kick off his 1980 Presidential campaign in Neshoba County, Mississippi with a speech declaring his belief in "states' rights" was intended to appeal to white racism, others admitted that "abstract" or coded language was deliberately employed to do exactly that. As Lee Atwater, a Reagan advisor explained it to a political scientist in the early 1980s, Republicans would win white Southern votes by continuing in the same tradition established in the 1960s. "You start out in 1954 by saying, 'Nigger, nigger, nigger," Atwater explained, "By 1968 you can't say 'nigger'-that hurts you. Backfires. So you say stuff like forced busing, states' rights and all that stuff." In the process the racial issues become "abstract," even if a "byproduct of them" is clearly a differential effect on racially identified groups and "blacks get hurt worse than whites." By 1980, the Republicans were "doing away with the racial problem one way or the other.... because obviously sitting around saying, 'We want to cut this,' is much more abstract than even the busing thing, and a hell of a lot more abstract than 'Nigger, nigger.'" (Lamis 26).

That these confessions are rare and severely outnumbered by examples of moderate speech by Nixon et al. is no accident. Political strategists understood that the successful deployment of a Southern strategy in a national election depended on moderate language, the appearance of sincerity (as opposed to cynical pandering), and the articulation of a national interest. "We should disavow Phillips' book [The New Republican Majority] as party policy," Nixon political strategist Harry Dent advised, but "stick with the silent majority theme." (Lassiter 2006, 241). Phillips, after all, had been fairly blunt in public about the "Southern strategy" and how this approach used knowledge about "who hates whom" to win elections (Carter 1996, 43). Although in private Nixon and his advisors were at times equally coarse about their political machinations, they carefully tuned their public speech. In South Carolina "Dirty Tricks" Dent once attempted to discredit a political opponent by publicizing a picture of him shaking hands with a black man. But as an advisor to the President, he declared in Time Magazine, "this country is bigger than the South... the President has to have a stance that's national." If Dent had "[taken] up the South's cause, waved the Confederate flag, and [run] all through the White House yelling and being parochial," he explained in 1969, it would have done more harm than good ("Nation: Up at Harry's Place" 1969). Even Southerners in the South weren't doing that any more. The President could win the votes of the extremists anyway, Dent advised privately, by "retreating from aggressive civil rights enforcement and making sure that voters blamed the Democrats for 'massive integration'" (Lassiter 2006, 241). Besides, moderate opposition worked as strategy. Protecting "neighborhood schools" prevented genuine and meaningful school desegregation from ever becoming a reality. That it permitted its adherents to express their support for Brown V. Board of Education at the same time was an added political bonus.

The basic premise of the "Southern strategy" also fits too neatly with some of what we know about the development of Southern politics. One of the most extraordinary contributions of recent works in Southern history has been the careful documentation of that surprisingly gradual, bottom-up transformation of the politics of race from simple, overt racism to one that preserves and defends racial privilege in more subtle 
ways, encapsulated in many cases within a single generation or the political careers of single individuals. It was accompanied by a gradual transformation of state and local politics in the South from support for conservative Democrats, who had rarely followed the lead of the national party anyway, to Republicans. As Dan Carter reminds us, George Bush Sr., embarked on his political career in Texas by running as a Republican challenger to an incumbent Democratic Senator who had voted in favor of what would become the Civil Rights Act of 1964. Bush did not defend segregation per se, but he expressed opposition to an "unconstitutional" abuse of federal power. "The new civil rights act was passed to protect 14 per cent of the people," he explained in a campaign speech; he was "worried about the other 86 per cent" who would be affected by it (Carter 1996, xi, xii). In Mississippi, white Republicans who took over the state's party apparatus likewise sold themselves not as a local opposition party but as an alternative more effective than the Democrats' defense of segregation. There is also an essential continuity across many individual cases of partisan shifts. Many Southern Democrats, like Senator Strom Thurmond of SC or Jesse Helms of NC retained essentially the same political positions for most of their careers and simply switched parties. While challengers to the "Southern strategy" interpretation have complicated this narrative by revealing its bottom-up qualities, the development of moderate language and strategy, the failures of extremism, or the slow evolution of partisan change at the state and local level, the basic shift in the second half of the twentieth century is hard to dismiss.

This is even more compelling if you consider who else in the United States would like for us to forget about the Republican party's links to the Southern strategy. Remember what happened in 2002 when Republican Senate Minority leader Trent Lott dredged up unwelcome memories of the roots of the Southern G.O.P. with a remark at Strom Thurmond's $100^{\text {th }}$ birthday party? Mississippi had voted for Thurmond when he was the States' Rights Party presidential candidate of 1948, Lott reminded the audience, and, he declared: "We're proud of it. And if the rest of the country had followed our lead, we wouldn't have had all these problems over all these years, either." According to the Washington Post, the comment drew "an audible gasp and general silence" even in that presumably sympathetic crowd. Newspaper stories registered the predictable liberal outcry and, in what was perhaps a revelation more caustic than their inevitable history primer on just what Thurmond and States' Rights stood for in 1948, the papers reminded readers that Lott had made essentially the same remark at a 1980 Jackson, Mississippi campaign event for the saintliest of all recent Republicans, Ronald Reagan. Some conservative pundits, like Pat Buchanan, defended Lott (and by extension Reagan) against what they saw as an unfair attack by a biased media. But mainstream Republicans, including the Bush White House, and many conservative intellectuals dropped Lott like a hot potato. "Oh God," William Kristol, editor of the conservative Weekly Standard, reportedly said, "It's ludicrous. He should remember it's the party of Lincoln." Lott's spokesmen attempted to deflect the criticism with a two-sentence statement that "Senator Lott's remarks were intended to pay tribute to a remarkable man who led a remarkable life. To read anything more into these comments is wrong." (Edsall 2002, 6) But it was nearly impossible not to, and Lott was ultimately forced to resign from his post as a Party leader.

21 Significantly, the Lott episode reveals some important things about American political memory: It is short and selective. Born in 1941, Trent Lott was an undergraduate student at Ole Miss in 1962 when students rioted to block the admission of James 
Meredith. He himself played a key role in blocking the integration of his national fraternity (Tumulty). After law school, Lott served as an aide to Democratic Congressman and signer of the notorious "Southern Manifesto," William Colmer. In 1967 Lott campaigned for the arch-segregationist gubernatorial candidate John Bell Williams. When Lott was elected to the House of Representatives in 1972, he entered as a Republican, but acted the Southern part, leading the fight against IRS regulations threatening the tax-exempt status of lily-white private schools in Mississippi and persuading Congress to restore citizenship to Confederate President Jefferson Davis (Crespino 211, 257-61). All the while he collected votes and warm support from the Council of Conservative Citizens, whose literature and rhetoric were littered with unapologetic paeans to white supremacy (Edsall, 1999, A2). None of this prevented Lott from becoming a Republican Party leader. No one really seemed to care much, and besides, Lott's positions and his ultra-conservative supporters could be easily attributed to his hardfast support for small government, fairness, heritage, states' rights, etc.

And yet, his praise of Thurmond-an offensive remark to be sure but one that really harmed no one except the Republican party-proved to be the one historical genie that could not be put back into the bottle of states' rights. When Lott stepped down, removing another smoking gun from prominent view, party leaders and conservative pundits emitted a nearly audible collective sigh of relief. Lott, Kristol optimistically asserted, was "really virtually the last of the products of Richard Nixon's 'Southern strategy' to be in major positions of power in the Congress, and with his leaving, you will have cleared out people who, fairly or unfairly, have a somewhat compromised image to the country as a whole" (Perdum A18). The funny ending to this story-or sad ending, depending on your politics-is that Lott rose again anyway. In 2007, the Republican party, praising his effectiveness and his legislative expertise, elevated him once again, this time to the position of minority whip. Lott supporter and future Republican Presidential candidate John McCain remarked that "We all believe in redemption... Thank God." (Leibovich 1). What redeemed Lott with the Republicans, however, was not his remorse (which did appear genuine) or reparations, but his political effectiveness in holding his Senate seat in 2006 and the work he did for the Party. "Lott could still get elected" plus "Lott helped the Republicans" equals "end of story."

Other twenty-first century Republican encounters with the Southern strategy betray a similarly cynical concern with the bottom line: election numbers. In 2005 the chairman of the Republican National Committee Kenneth Mehlman admitted to an NAACP audience that in the 1960s the Republicans "gave up on winning the African American vote, looking the other way or trying to benefit from racial polarization." And "we were wrong." Mehlman did not own up to just what "racial polarization" had meant in the trenches: the offensive advertisements, the preservation of racial stereotypes (black criminals and welfare queens), or the policies that perpetuated segregation. Instead he focused on selling a "new opportunity for the party of Lincoln and for the African American community to restore our historic bonds." CNN anchor John King asked Mehlman pointblank "If a Republican candidate in the next election cycle uses the confederate flag [as Republican Governor Sonny Perdue had in 2002]... will [you] and the president of the United States, George W. Bush, stand up and say 'stop' and cut off their money?" Mehlman waffled. The Governor of Georgia, he said, was a "good man" who was doing a "fantastic job of reaching out," and had won "a significant percentage 
of the African American vote" (CNN late edition)-even though Perdue actually carried a lower percentage of black votes (6\%) than his Republican counterparts in 1994 (10\%) or 1998 (8\%) (Hayes and McKee 8). Fortunately Perdue never forced anyone to "stand up"-at least not in 2005. On the other hand, Republican remorse over the Southern strategy had not stopped Perdue from courting the Flaggers' votes in the tight election of 2002. The portion of the electorate that reliably responds to such new-fangled but old-style "Southern" appeals may have diminished, but it is clearly still an important, and perhaps a critical margin in some elections.

In this country of fresh starts and second chances, Americans like to leave what are often ugly historical truths behind. Even George Wallace earned redemption for renouncing his segregationist past-enough to win a substantial number of black votes in his fourth successful campaign to become governor of Alabama in 1982. Of course it helps that Americans have short memories. In Georgia, defenders of the old Stars-andBars state flag, nearly five decades removed from its original installation, willfully ignored the fact that it was a symbol of the 1950s rather than the 1860s and demanded its reinstallation in the name of yet another newly sanitized history of states' rights, the Confederacy. But the problem is greater than forgetting. Many candidates who have, and would continue to, exploit racial polarization to win votes want to rewrite history to suit their needs. In the 1980s Strom Thurmond defended his run as the Dixecrat's Presidential candidate as merely an effort "to protect the rights of the states and the rights of the people," and not the "race fight" it was subsequently labeled by "some in the news media." (Noah 2011). When presented with a transcript and film footage of his 1948 speech where he declared, "There's not enough troops in the Army to force the Southern people to break down segregation and admit the Negro race into our theaters, into our swimming pools, into our homes, and into our churches, "the Senator's aides responded with shock and Thurmond himself with "incredulity," according to biographer Nadine Cohodas. Once he was convinced that the excerpt was indeed a genuine record of his speech, Thurmond remarked, "If I had to run that race again...I would word it differently" (Cohodas, 177). ${ }^{3}$ The words mattered, because once "segregation" and "Negro" were part of the record, it was much harder to defend as an abstract position on "states' rights."

In 2010 Haley Barbour, a veteran of Nixon's 1968 campaign, attempted a similar whitewashing of Mississippi and his own history in The Weekly Standard. Barbour "just [didn't] remember [the civil rights era] as being that bad." Contrary to what people might have thought "up north," Barbour claimed, the Yazoo County Citizens' Council was "an organization of town leaders" that actually kept the peace and the Klan out (Ferguson). Barbour's reconstruction was, in some very technical but ultimately meaningless sense, at least partly correct since that's how it may have appeared to white people. As Joe Crespino recounts, Yazoo City avoided headline-grabbing violence, while the Citizens' Council fought desegregation with intimidation and the discipline of white pocketbooks. In 1955, the Citizens' Council published the name and address of every parent who had petitioned the local school board to desegregate city schools in the local paper and displayed the same list of names in every store window in town. All but two of the petitioning parents "suffered some form of economic reprisal, most of them losing their jobs or businesses" (Crespino 29). Yazoo County whites may not have permitted interference by the Klan, but they didn't need it anyway. 
In response to criticism of his selective memory, Barbour issued a statement redescribing the Citizens' Council as "totally indefensible, as is segregation." But Barbour curiously misremembered other aspects of his own past, disingenuously claiming that "his generation" went to integrated schools (though he did not) and recalling a chummy relationship with Verna Bailey, the first black woman to attend Ole Miss (who had no memory of him). When Barbour's name popped up as a potential Presidential candidate in 2012, all his trials with racial insensitivity, including his association with the Council of Conservative Citizens, became fair game once again. Newsweek columnist Ben Adler commented that even if Barbour's racial indiscretions disqualified him from candidacy, it made little difference in terms of Republican racial policy-except for his tendency toward incriminating gaffes, Barbour was "substantively no different on racial issues from his primary opponents" (Adler). But politically, Republicans and conservative pundits know, Barbour's link to Southern racism was a deal breaker for those who like to think of themselves as racially enlightened conservatives. If only because Barbour is a white Southerner from Mississippi of a certain age, making him a national figurehead in the Republican party would inevitably invite suspicion of the motives behind the usual G.O.P. cry of fiscal and social conservatism. Should the Republicans ever finally be successful at disowning the "Southern strategy," however, it would certainly make their positions easier to defend as colorblind.

27 As a scholar, based on my own research and that of others, I do believe that there was a Southern strategy, even if the project of correctly characterizing it is ongoing. I am convinced, also, by the new literature that it is a very complicated phenomenon, influenced by multiple factors. I'm painfully aware that maintaining the idea of the Southern strategy as the source of modern conservatism entails other kinds of oversimplifications and compromises by those of us who care about setting the racial record straight, and that if we want to get it exactly right we have to be more sophisticated. I also agree that one of the problems with talking about the Southern strategy in particular, and Southern Exceptionalism in general, is that it has prevented Americans from having a deeper understanding of the history and context in which recent political conservatism developed. While no one denies that racial elements were central to the history, a Southern focus lets all the other white Americans who remain convinced of their own racial innocence off the hook, while strengthening the myth that the white South was the odd outlier in an otherwise racially liberal, fair-minded political culture. This myth, deeply etched in Americans' collective popular memory, has undoubtedly misrepresented and obscured the nature of American racism.

However, as with all myths, there is an essential kernel of "truth" at the heart of the "Southern strategy" that scholars must address. Southern white voters were distinctive and remain distinctive in their overwhelming support of modern conservative politics in the twenty-first century. Some contemporary white Southern voters are recent migrants to the region, but many are the very same people who cast votes in 1968-I know some of them in fact. To a large extent, white racial "innocence" is undoubtedly a persistent theme, as middle and upper class whites can afford to be cavalier about government programs and social welfare policies that do not benefit them. It's also undoubtedly true, as Joe Crespino and Lisa McGirr have shown, that the rejection of liberalism increasingly had as much to do with conservatives' concern about social values as it did civil rights. The conservatives' agenda has broadened considerably beyond the economic and civil rights issues at the forefront in the 1960s. But the South 
still stands out with respect to race and region. As Dan Carter has pointed out for the 2004 election returns, white Southerners are almost twice as likely as white Americans elsewhere to vote for Republicans. In 2004, 52\% of white Americans in households earning from $\$ 30,000$ to $\$ 100,000$ and $58 \%$ of those earning more than $\$ 100,000$ per year voted for President George Bush, while $74 \%$ of white Southerners earning $\$ 30-100,000$ voted for Bush and the percentage of wealthy white Southerners was even higher (Carter 2007).

The 2008 Presidential election likewise revealed an even more distinctive pattern among Southern whites. Although Barack Obama failed to win the majority of white votes nationwide, his support from whites in the deep South was markedly lower-just $10 \%$ in Alabama, $11 \%$ in Mississippi, $14 \%$ in Louisiana, 23\% in Georgia and 26\% in South Carolina. In Florida, North Carolina and Virginia, the Southern states carried by Obama, he won just $42 \%, 35 \%$, and $39 \%$ of white votes. Even in Arizona and Alaska, the home states of John McCain and Sarah Palin, Obama won $32 \%$ and $40 \%$ of the white vote respectively. Only in five other states - Idaho, Kentucky, Oklahoma, Utah and Wyoming -did the white vote for Obama dip under $35 \%$ (Noah 2008). Racism probably prevented some whites from voting for Obama, but it would be foolish and somewhat simplistic to assume this of the majority-that isn't the point. Many Southern whites would be unlikely to vote for a Democrat, no matter their racial identity or beliefs about race, for many reasons. But even if this is a new incarnation of Southern white identity different from the racist reactionaries that conventional wisdom has associated with the late 1960 s and early 1970 s or even the 1980s, it does appear to be a racial, regional identity, just one generation removed from segregation.

It would be a shame if arguments over the success or failure of the Southern strategy as an explanatory mechanism or over the "myth" of Southern history prevented us from examining such regional and racial continuity as we struggle to put the last fifty years of American political history in perspective. There are, as so many recent books have persuasively argued, many reasons to doubt that Southern whites were the tail that wagged the dog of Republican ascendancy. There are also many reasons to think, as Lassiter and Crespino argue so persuasively, that much of what were once believed to be differences of kind are really differences of degree. But the white South of the Southern strategy is not simply a historian's creation. Rightly or wrongly contemporaries also believed in it and many white Southerners acted in ways that appeared to affirm it. Although many Republicans would like to forget, many have not. In 1981, a repentant Harry Dent, who had given up his legal and political work to "follow the Lord, full time," admitted that his "biggest regret" about his political career was "anything I had done to stand in the way of the rights of black people." (Sawyer).

Recent works in Southern history have been sensitive to the conceptual confusion between the South in American memory and the South of American history. We historians struggle to get the history right, but surely one of our goals in doing so is to improve the memory of the public in these matters we consider so important. We must seek to modify the public's distorted memory of the South, but we also have to preserve those elements whose place in memory serve as reminders of some of the more repulsive historical truths about the United States. For better or worse, the partially false memory of the "Southern strategy" is one of the few, if not the only, modern instances where Americans actually do remember that "states' rights," "freedom of association," or the Confederate battle flag have loaded meanings-racist meanings- 
beyond what is immediately apparent in the words or the image. Even if, as many historians now argue, the link between the Southern segregationist past and America's conservative present is not the whole story, it's a large part of the story and provides the most damning reconstruction of colorblind politics there is. For while the presentday opponents of "special treatment" or "judicial remedies" may deny that America has a problem with racism, no one with a prayer of getting elected or influencing opinion would defend the Jim Crow South or the tactics used to perpetuate segregation. "States' rights" has only worked as an amoral mantra of national conservatism when stripped of its ties to white Southern heritage.

Regardless of whether we as historians think there "really" is a South or not anymore, there is in the public mind an idea of the South and a Southern identity. The idea is in many ways pernicious and ought to be revised to more accurately reflect our American truth. But ideas, like memory, have their own reality nonetheless, and in matters of identity ideas can be incredibly powerful. Those in Georgia who sought to return Confederate stars and bars to the state flag did so for some reason. Perhaps those white Georgians do not remember how the stars and bars got there. Perhaps they genuinely believed, as a Dodge County member of the Sons of Confederate Veterans opined, that the flag is "for all people that fought in the civil war whether they were white, black, red, yellow, the Hispanic, the Jews" ("Dodge County NAACP"). And one response to flaggers would be to argue that they really are no longer that different from other Americans and have no distinctiveness worthy of recognition. But another would be to point out that their symbols have a history that almost no one would defend.

\section{BIBLIOGRAPHY}

Adler, Ben. "Haley Barbour's Historical Amnesia: The governor's fond recollection of a racist organization could be a liability." Newsweek 21 Dec. 2010. Web. 11 May.

<http://www.newsweek.com/2010/12/21/haley-barbour-s-historical-amnesia.html>

Bennet, Josephine. "Flag Causing Controversy." Georgia Public Broadcasting News 22 Apr. 2011. Web. 16 May.

< http://www.gpb.org/news/2011/04/22/flag-causing-controversy>.

Black, Earl and Merle Black. The Rise of Southern Republicans. Cambridge: Harvard University Press, 2003.

Boone, Christine.“County votes to keep Rebel flag flying." Atlanta Journal Constitution 22 Apr. 2011: 3B.

Boyd, James. "Nixon's Southern Strategy: 'It's All in the Charts."” New York Times 17 May: 25, 104-111.

"CNN Late Edition transcript," 17 July. Web. 25 May.

<http://transcripts.cnn.com/TRANSCRIPTS/0507/17/le.01.html.> 
Carter, Dan. From George Wallace to Newt Gingrinch: Race in the Conservative Counterrevolution, 1963-1994. Baton Rouge: LSU Press, 1996.

---. "Is There Still a South? And Does it Matter?" Dissent (Summer 2007). Web. 10 May.

Cohodas, Nadine. Strom Thurmond and the Politics of Southern Change. New York: Simon and Schuster, 1993.

Campbell, Colin. “Georgia's Flag Fight Could Get Messy-Once Again.” Atlanta Journal Constitution 9 Jan. 2001: 8B.

Crespino, Joseph. In Search of Another Country: Mississippi and the Conservative Counterrevolution. Princeton: Princeton University Press, 2007.

“Dodge County NAACP Wants Confederate Flag Taken Down." WMGT 41, Macon GA 4 May video. Web. 11 May.

< http://www.41nbc.com/news/local-news/3983-dodge-county-naacp-wants-confederate-flagtaken-down>.

Edsall, Thomas B. "Lott Decried For Part Of Salute to Thurmond; GOP Senate Leader Hails Colleague's Run As Segregationist.” Washington Post 7 Dec. 2002: A6.

---. “Controversial Group Has Ties to Both Parties in South.” Washington Post 13 Jan. 1999: A2.

Erlichman, John. Witness to Power: The Nixon Years. New York: Simon and Schuster, 1982.

Ferguson, Andrew. “The Boy from Yazoo City: Haley Barbour, Mississippi's favorite son.” The Weekly Standard 16.15 (27 Dec. 2010). Web. 11 May.

http://www.weeklystandard.com/articles/boy-yazoo-city_523551.html.

Galloway, Jim. "Perdue to seek 2004 referendum on flag." Atlanta Journal-Constitution 12 Feb. 2003: $1 \mathrm{~A}$.

---.“For '56 flaggers, it's not over yet.” Atlanta Journal-Constitution 4 Jan. 2004: 1D.

---. “Airborne 'flaggers': Who's paying?” Atlanta Journal-Constitution 28 May: 1A.

Hayes, Danny and Seth C. McKee. "Booting Barnes: Explaining the Historic Upset in the 2002 Georgia Gubernatorial Election.” Politics and Policy 32 (Dec. 2004): 1-31.

Jackson, Edwin L. "State Flags of Georgia," in The New Georgia Encyclopedia Updated 3 Mar. 2009. Web. 16 May

<http://www.georgiaencyclopedia.org/nge/Article.jsp?id=h-2671>.

Kruse, Kevin Michael. White Flight: Atlanta and the Making of Modern Conservatism. Princeton: Princeton University Press, 2005.

Lamis, Alexander P. Southern Politics in the 1990s. Baton Rouge: Louisiana State University Press, 1999.

Lassiter, Matthew D. "The Suburban Origins of "Color-Blind" Conservatism

Middle-Class Consciousness in the Charlotte Busing Crisis"

Journal of Urban History 30 (May 2004): 549-582.

---. The Silent Majority: Suburban Politics in the Sunbelt South. Princeton: Princeton University Press, 2006.

Lassiter, Matthew D., and Joseph Crespino, The Myth of Southern Exceptionalism. New York: Oxford University Press, 2009. 
Leibovich, Mark. “In Senate Shift, Big Comeback for Trent Lott.” New York Times 16 Nov. 2006: A1.

Lesher, Stephen. George Wallace: American Populist. New York: Da Capo Press, 1994.

Martinez, Michael. "The Georgia Confederate Flag Dispute.” Georgia Historical Quarterly 92 (summer 2008): 200-228.

McGinnis, Joe. Selling of the President, 1968. New York: Pocket Books, 1970.

McGirr, Lisa. Suburban Warriors: The Origins of the New American Right. Princeton: Princeton University Press, 2002.

“Nation: Up at Harry's Place." Time 11 July. Web. 21 May.

http://www.time.com/time/magazine/article/0,9171,900972,00.html.

Noah, Timothy." The Legend of Strom's Remorse: A Washington lie is laid to rest, " Slate Mag., 16 Dec. 2002. Web. 16 May.

< http://www.slate.com/id/2075453/>.

---. "What we didn't overcome, part 2," Slate Mag. 12 Nov 2008. Web. 23 May.

< http://www.slate.com/id/2204464/\#sb2204528>.

"Phew: Another new flag-and a rough baptism for the new governor." The Economist 1 May. Web. 16 May.

<http://www.economist.com/node/1753469?story_id=E1_TSVPQGJ>.

Perdum, Todd S. “ Divisive Words; A Nixon-Era Distraction Steps Out of Limelight.” New York Times 21 Dec. 2002: A18.

Poundstone, William. Gaming the Vote: Why Elections Aren't Fair (and What We Can Do About It). New York: Macmillan, 2009.

Richards, Doug. "Confederate flag padlocked to flagpole at Dodge County Courthouse." 11Alive News. 4 May. Web. 11 May.

<http://www.11alive.com/rss/article/189891/3/Confederate-flag-padlocked-to-flagpole-atDodge-County-Courthouse>.

Rieder, Jonathan." Rise of the Silent Majority. " In Rise and Fall of the New Deal Order, 1930-1980. Ed. Gary Gerstle and Steve Fraser. Princeton: Princeton University Press. 243-69.

Riley, Michael, Don Winbush and Richard Woodbury." Louisiana: The No-win Election. ” Time 25 Nov. 1991. Web. 25 May.

<http://www.time.com/time/magazine/article/0,9171,974345,00.html\#ixzz1NegicU6n>

Sawyer, Kathy.“A Repentant harry Dent Will Follow the Lord” Washington Post 22 Aug 1981: A3.

Shaefer, Byron E. and Richard Johnson. The End of Southern Exceptionalism: Class, Race, and Partisan Change in the Postwar South. Cambridge, Mass.: Harvard University Press, 2006.

Sugrue, Thomas. The Origins of the Urban Crisis: Race and Inequality in Postwar Detroit. Princeton: Princeton University Press, 1996.

Torpy, Bill. “Confederate Flag Controversy; Heritage vs. hate at heart of dispute." Atlanta JournalConstitution 15 May: 1B.

Tumulty, Karen. “Trent Lott's Segregationist College Days.” Time 12 Dec. 2002. Web. 25 May. http://www.time.com/time/nation/article/0,8599,399310,00.html.

Wilson, Charles Reagan and Mark Silk. Religion and Public Life in the South: In the Evangelical Mode. Walnut Creek, [Calif.] : AltaMira Press, 2005. 


\section{NOTES}

1. The new Georgia flag was deemed the "worst-designed state or provincial flag in North America" by the North American Vexillogical Association. Jackson, "State Flags of Georgia."

2. "Most Southern" from the title of James C. Cobb's The Most Southern Place on Earth: The Mississippi Delta and the Roots of Regional Identity (1994).

3. I found this quotation through Timothy Noah's article in Slate Magazine.

\section{ABSTRACTS}

This paper examines recent historical arguments against relying upon "Southern exceptionalism" and the "Southern strategy" to explain late twentieth-century partisan realignment. While acknowledging the seminal contributions of this new literature, the article examines some of the historical evidence supporting the traditional interpretations of the Southern strategy and some of the ways that the "Southern strategy" has figured into recent American politics. Though the emphasis on the South has distorted the memory of overall American resistance to civil rights and social change, the article suggests that Southern history nevertheless plays a unique and important role as a reminder of American resistance and the race-based origin of many colorblind social policies.

Cet article étudie les arguments récemment avancés par les historiens pour remettre en question l'explication du réalignement partisan de la fin du 20e siècle, fondée sur l'“exceptionnalisme sudiste" et la "stratégie sudiste". Tout en reconnaissant les apports majeurs de ces nouveaux travaux, l'article souligne certains éléments historiques tendant à prouver la validité des interprétations traditionnelles de la stratégie sudiste et de la manière dont cette dernière a influencé la politique américaine récente. Si le fait de porter l'accent sur le Sud a déformé la façon dont on se souvient de la résistance américaine à la reconnaissance des droits civiques et au changement social, cet article suggère cependant que l'histoire du Sud joue un rôle unique et important de révélateur de la résistance nationale et des fondements raciaux de nombreuses politiques sociales censées être racialement neutres.

\section{INDEX}

Mots-clés: stratégie sudiste, exception sudiste, drapeau confédéré, majorité silencieuse Keywords: Southern strategy, Southern exceptionalism, Confederate flag, silent majority 
AUTHORS

MICHELLE BRATTAIN

Associate Professor of History

Georgia State University

mbrattain@gsu.edu 